\title{
EVALUATION OF A CERTAIN COTTON GERMPLASM FOR RESISTANCE AGAINST FUSARIUM WILT FUNGUS UNDER GREENHOUSE CONDITIONS IN 2016
}

\author{
ASRAN, AMAL A., M. T. M. MANSOUR, M. S. KHALIL, \\ A. Z. A. ASHOUR, MARIAN M. HABEB and A. A. ALY
}

Plant Pathol. Res. Instit., ARC, Giza, Egypt.

(Manuscript received 10July 2016)

\begin{abstract}
$\mathrm{T}$ he germplasm evaluated in this test was a part of the Screening Program for Fusarium Wilt Resistance. This program is conducted annually in the greenhouses of Cotton and Fiber Crops Diseases Research Dept, PPRI. The present test included 200 families of ten experimental genotypes and 745 families of seven commercial cultivars. The experimental genotypes were supplied by Cotton Breeding Dept, and the commercial cultivars were provided by Cotton Maintenance Dept, Cotton Research Institute. Healthy survival rate of plants of the families was used as a criterion to evaluate the reactions when the genotypes were grown in autoclaved highly infested soil with a mixture of race3 of Fusarium oxysporum f.sp. vasinfectum isolates. The experimental genotypes, except G5 and G8, showed distinguished range of resistance to Fusarium wilt as expressed by healthy survival ranging from 97.28 to $100 \%$., thus, classified as very highly resistant (VHR). Within this narrow range, no significant differences in resistance could be observed; significant differences, were however, observed between G5 or G8 and any of the other VHR genotypes as well. The difference between G5 and G8 was also significant. The experimental genotypes were classified into three distinct groups based on the dissimilarity distance (DDs) generated from cluster analysis of their symptom profiles. The first group included $\mathrm{G} 1, \mathrm{G} 3, \mathrm{G} 2, \mathrm{G} 7, \mathrm{G} 6, \mathrm{G} 4, \mathrm{G} 9$, and G10.The second group included G8.The third group, which was unrelated to the previously mentioned two groups, included G5). Within the first group, genotypes were identical in their symptom profiles. Most of the families of the tested commercial cultivars were classified as VHR. The percentages of families in this reaction class ranged from 86.92 (families of Giza 45) to $100 \%$ (families of each of Giza 86 and Giza 88). The commercial cultivars were classified into two distinct unrelated groups based on the DDs generated from cluster analysis of the profiles of their reaction classes. Giza 45 was included in one group and the remaining cultivars. were included in the other group.
\end{abstract}

Key Words: Cotton, Fusarium wilt, race3, Fusarium oxysporum f.sp.vasinfectum, Germplasm. 


\section{INTRODUCTION}

Fusarium wiltof cotton is a serious fungal disease responsible for significant losses throughout the world. The causal organism Fusariumo xysporum Schlecht.f.sp. vasinfectum (ATK) Snyd and Hans (FOV), invades the host through the taproots behind the root tip. The combined effect of fungal metabolites and the production of lipodial substances by the host in response to infection may lead to occlusion of the vascular tissue, resulting in wilt of the cotton plant (Hillocks, 1984).The pathogen can survive for several decades in soil and cannot be eradicated from infested fields. The pathogen can infect cotton at all stages of growth and produces symptoms, which include seedling death, wilting, vascular discoloration and plant death (Watkins,1981).

Apart from, Egypt, it is commonly associated with nematode infection [root knot- Fusarium wilt complex(McFadden et al., 2004)], particularly in acidic, sandy soils. In Egypt, where cotton is grown in alkaline clay soils, there is no evidence for the involvement of nematodes in Fusarium wilt disease (Aly et al., 2000).

Currently, up to eight races of (FOV), most of which are geographically separated, are recognized worldwide. The basis for determining races of FOV depends on their virulence to a differential set of cotton(Gossypium) lines and species and up to 5 non- cotton hosts (Watkins,1981).

The Egyptian race (race 3) of FOV has long been known in the Nile Vally, where it remains one of the most damaging pathogen on Egyptian cottons(Gossypium brbadense L.).This race also attacks G.brbadense in the former Soviet Union(Watkins,1981). and Israel (Netzer et al, 1985).

FOV caused serious losses in the commercial Egyptian. Cottons(G.brbadense L.) in the late fifties (Barky et al., 1958). Since then, extensive cotton breeding programswereconducted to develop cultivars resistant to the disease.

Breeding materials submitted by cotton breeders (Cotton Research Institute) have been screened for resistance under greenhouse conditions in soil highly infested with FOV. This test has been conducted annually for the past 60 years in the greenhouses of Cotton and Fiber Crops Diseases Research Dept, PPRI,ARC.The program has been successful enough in developing highly resistant cultivars. (Aly et al, 2000).

Fusarium wilt remains a potential threat to cotton production in Egypt because FOV is still well established in the Egyptain soil (Aly et al, 2000). Thus, 
increasing the probability that new races other than race 3 or new biotypes of this race may arise to confound cotton breeders.

The objective of the present study was to evaluate a collection of cotton germplasm against Fusarium wilt race 3 under greenhouse conditions by using families of experimental genotypes and commercial cultivars.

\section{MATERIALS AND METHODS}

\section{Cotton germplasm}

The germplasms used in this study included 200 families of ten experimental genotypes (Table 1) supplied by Cotton Breeding Section, as well as 745 families of six commercial cultivars( Table 5) supplied by Cotton Maintenance Section, Cotton Research Institute.

\section{Evaluation of cotton germplasm against Fusarium wilt race 3 under greenhouse conditions.}

This study was conducted in the greenhouses of Cotton and Fiber Crops Diseases Research Dept,PPRI through 2016.The experimental design used in this study was a completely randomized with three replications (pots) for each genotype.

The fungal inoculum used in the greenhouse test was a mixture of equal parts $(w / w)$ of 50 isolates of FOV race 3. These isolates were obtained from the fungal collection of Cotton Pathology Dept, PPRI, Giza. Autoclaved clay loam soil was infested with a mixture of the isolates at a rate of $10 \mathrm{~g} / \mathrm{kg}$ soil, prepared in $500-\mathrm{ml}$ glass bottles, each bottle contained $50 \mathrm{~g}$ of sorghum grains and $40 \mathrm{ml}$ of tap water. The inocula made from one- week old culture on PDA, and allowed to colonize sorghum for 3 weeks. Infested soil was dispensed in $10-\mathrm{cm}$ diameter clay pots, which were planted with 10 seeds per pot..The greenhouse was equipped with a heating system assuring that the minimum temperature in the greenhouse was maintained at $28^{\circ} \mathrm{C}$; however, due to the lack of cooling system, the maximum temperature was out of control fluctuating from 30 to $35{ }^{\circ} \mathrm{C}$ depending on the prevailing temperature during the day ( the test was conducted in January and February, 2016).

\section{Assessment of Fusarium wilt incidence}

Percentages of infected seedlings were recorded 45 days from planting date. The infected seedlings included the dead and the surviving seedling, which showed external or internal symptoms. The external symptoms usually began at the margin of 
cotyledons as yellowing along the veins (vein clearing), eventually, the entire cotyledonds turned yellow and dropped from the seedlings. Seedlings that remained apparently healthy 45 days after planting were cut diagonally across the root and stem to examine the internal symptoms. If discoloration of xylem vessels was observed, they were considered infected. If seedlings were free of such a discoloration, they were considered healthy. Thus, the seedlings of each genotype were placed in two distinct classes: healthy if they were free of any external or internal symptoms,or infected if the seedlings died or survived showing any external or internal symptoms. ( Aly et al.,2007 and Abd-Elsalam et al.,2009).

\section{Statistical analysis of the data}

Data were subjected to analysis of variance and Least significant difference (LSD) was calculated to compare between genotype means. Linear correlation coefficients were calculated to measure the degree of association among wilt symptoms on the genotypes. the tested genotypes were clustered by the average linkage technique (unweighted pair-group method) based on the profiles of their reaction classes. Statistical analysis was performed with the software package SPSS6.0.

\section{RESULTS}

Families within each of the tested genotypes showed variable symptom expression (Table 2) due to the fact that many of these genotypes were not pure lines. However, with the exception of G5 and G8, the majority of the families of each genotype were completely free of any internal or external symptoms (healthy survival).

The highest correlations among symptom expressions were observed between vascular discoloration and each of dead seedlings $(r=0.967, p=0.000)$ and healthy survival $(r=0.947, p=0.00)$ (Table3).

Healthy survival rate was used as a criterion to evaluate the reactions of the tested genotypes to Fusarium wilt (Table 4). The tested genotypes, except G5 and G8, showed a nearly similar range of resistance to Fusarium wilt with healthy survival rates ranging from 97.28 to $100 \%$. Thus, classified as very highly resistant (VHR). Within this narrow range, no significant differences were observed. However, significant differences were observed between G5 orG8 and any of the other VHR genotypes. The difference between G5 and G8 was also significant.

A phenogram based on dissimilarity distance (DD) generated from cluster analysis of symptom profiles of the tested genotypes is presented in Fig.1. Thes 
maller the $\mathrm{DD}$, the more closely the genotypes were related in their symptom profiles. Three groups of genotypes were identified by cluster analysis. The first group included G1,G3,G2,G7,G6,G4,G9, and G10. The second group included G8. The third group, which was unrelated to the previously mentioned two groups, included G5. Within the first group, the genotypes were identical in their symptom profiles.

Most of the families of the tested commercial cultivars were classified as VHR. The percentages of families in this reaction class ranged from 86.92(families of Giza 45 ) to $100 \%$ (families of each of Giza 86 and Giza 88).

A phenogram based on dissimilarity distance (DD) generated from cluster analysis of the profiles of reaction classes of the tested cultivars is presented in Fig.2. TWO unrelated groups of cultivars were identified by cluster analysis. Giza 45 was included in one group and the remaining cultivars were included in the other group.

\section{DISCUSSION}

In the present study, genotypes were screened against $50 \mathrm{FOV}$ isolates from almost all cotton growing areas in Egypt. The use of such a large number of isolates is a strategy to maximize the probability that resistant genotypes identified under greenhouse conditions will maintain their resistance levels under field conditions in distinct geographic locations. On the contrary, if genotypes were screened against a limited number of isolates, they may not perform as expected due to potential presence of isolates differing in their virulence profile from those used in the greenhouse test.

A distinctive characteristic of Fusarium wilt is the olive brown discoloration of the root and stem xylem. However, there is no consensus regarding the diagnostic importance of this vascular discoloration for evaluation of the host germplasm reaction to Fusarium wilt. For example, Armstrong and Armstrong (1978) stated that vascular discoloration is a questionable standard for judging susceptibility to wilt in seedling tests. Zink et al. (1983) found no clear relationship between the severity of external symptoms in surviving muskmelon seedlings and the extent and degree of internal vascular discoloration. On the other hand, Salgado et al. (1994) used vascular discoloration as a criterion for judging susceptibility of tepary bean (phaseoulus acutifolius Gray) seedlings to Fusarium wilt. Osman (1996) found a highly significant correlation $(r=0.98, p \leq 0.01)$ between external wilt symptoms and vascular discoloration of cotton seedlings (cultivar Giza74). In the present study, we used more rigorous criteria for disease rating. According to these criteria, the seedlings were 
considered slightly susceptible if they showed internal discoloration even though they were free of external symptoms. Thus, the seedlings were considered resistant only if they were completely free of any internal and external symptoms. In our study, cotton genotypes were screened under very favorable conditions for FOV development. The soil was sterile, temperature was optimal most of the time, and the inoculum density was relatively high. Under these conditions, it is unlikely that any susceptible genotypes would have escaped from infection. However, one should keep in mind that evaluation in the greenhouse precludes identifying genotypes that may possess useful levels of field resistance to wilt. The soil infestation method, which we used for seedling inoculation, had several advantages. Assays were simple and did not damage the seedlings and provided discriminating and reproducible disease reactions. Since no cotton wilt nurseries have been established in Egypt, greenhouse tests will continue to be the only reliable method for screening cotton breeding materials for Fusarium wilt resistance. The current absence of Fusarium wilt in commercial cotton field using cultivars derived from our breeding program demonstrates the reliability of these screening procedures, which we have adopted in testing cotton genotypes for Fusarium -wilt resistance. The most successful strategy to manage Fusarium wilt is the use of resistant cultivars( Doan and Davis, 2014). Therefore the present work provides new and useful sources of resistance that might be employed in breeding programs aiming to develop cotton cultivars with resistance to FOV race 3 isolates.

Table 1. Experimental Genotypes supplied by Cotton Breeding Section, Cotton Research Institute in 2016.

\begin{tabular}{|c|c|}
\hline Genotype ${ }^{a}$ number & Pedigree \\
\hline G1 & [(G89x Karashinky)xG86] x (10229 x G80) \\
\hline G2 & (Giza89 xPima S6)x[(Bahteem 105xG67)]x(G72xDelcero)]x(G89 x G80) \\
\hline G3 & $(\mathrm{G} 85 \times \mathrm{G} 86) \times[(\mathrm{G} 83 \times \mathrm{G} 80) \times \mathrm{G} 89]$ \\
\hline G4 & 10229 x G86 \\
\hline G5 & [(G83 x G80)x G89] x Australian \\
\hline G6 & [G83 x( G75x 8544] xG80/1 \\
\hline G7 & {$[\mathrm{G} 83 \times(\mathrm{G} 75 \times 8544] \times \mathrm{G} 80$} \\
\hline G8 & GB58 x G90 \\
\hline G9 & $(\mathrm{G} 45$ x G84 XG70 x51B) B12XG97 \\
\hline G10 & G93 \\
\hline
\end{tabular}

a Each genotype was represented by 20 families. 
Table 2. symptoms used in evaluating the reactions of cotton genotypes to Fusarium wilt disease under greenhouse conditions in 2016.

\begin{tabular}{|c|c|c|c|c|}
\hline Genotypes $^{a}$ & & Symptoms (\%) & & \\
\hline Number & DS $^{\mathbf{a}}$ & CY & VD & HS \\
\hline G1 & $0.00^{\mathrm{b}}$ & 0.17 & 0.33 & 99.50 \\
\hline $\mathbf{G 2}$ & 0.00 & 2.05 & 0.17 & 99.83 \\
\hline G3 & 0.00 & 0.33 & 0.33 & 99.34 \\
\hline G4 & 0.00 & 2.50 & 0.00 & 97.50 \\
\hline G5 & 53.67 & 9.50 & 14.67 & 22.16 \\
\hline G6 & 0.33 & 0.00 & 0.00 & 99.67 \\
\hline G7 & 0.00 & 0.00 & 0.00 & 100.00 \\
\hline G8 & 0.00 & 41.00 & 5.00 & 48.00 \\
\hline G9 & 0.33 & 1.55 & 0.00 & 98.12 \\
\hline G10 & 0.33 & 0.00 & 2.39 & 97.28 \\
\hline
\end{tabular}

aDS= Deed seedlings, $\mathrm{CY}=$ Cotyledonary yellowing, VD = Vascular discoloration, and HS $=$ Healthy survival. ${ }^{\text {bMean }}$ of 20 replicates(families).

Table3.Correlation coefficients among symtoms used in evaluating the reactions of cotton genotypes to fusarium wilt disease under greenhouse conditions in 2016.

\begin{tabular}{|l|l|l|l|}
\hline & & Symptoms & \\
\hline Symptoms & \multicolumn{1}{|c|}{$\mathbf{X 1}$} & $\mathbf{X 2}$ & $\mathbf{X 3}$ \\
\hline Deed seedlings(X1) & & & \\
\hline & & & \\
\hline Cotyledonary yellowing(X2) & $0.218^{\mathrm{a}}(0.546)^{\mathrm{b}}$ & & \\
\hline Vascular discoloration(X3) & & & \\
\hline & $0.967(0.000)$ & $0.408(0.0 .241)$ & \\
\hline Healthy survival(X4) & & & $-0.947(0.000)$ \\
\hline
\end{tabular}

aLinear correlation coefficient.

bProbability level and $n=10$ 
Table 4. Reactions of some experimental cotton genotypes to fusarium wilt disease under greenhouse conditions in 2016.

\begin{tabular}{|c|c|c|}
\hline Genotypes ${ }^{\mathrm{a}}$ no. & Healthy Seedling b \% & Reaction class $^{\mathrm{c}}$ \\
\hline G1 & $99.50^{d}$ & VHR \\
\hline G2 & 99.83 & VHR \\
\hline G3 & 99.34 & VHR \\
\hline G4 & 97.50 & VHR \\
\hline G5 & 22.16 & HS \\
\hline G6 & 99.67 & VHR \\
\hline G7 & 100.00 & VHR \\
\hline G8 & 48.00 & $\mathrm{~S}$ \\
\hline G9 & 98.12 & VHR \\
\hline G10 & 97.28 & VHR \\
\hline
\end{tabular}

$\operatorname{LSD}(P \leq 0.05)$

aPedigrees of the tested genotypes are shown in Table1.

bSeedlings, which were completely free from any external or internal symptoms.

'Reaction class was determined based on the percentage of healthy seedlings according to the following scale:-

Very highly susceptible $(\mathrm{VHS})=0-10$

highly susceptible (HS) $=11-30$

Susceptible $(\mathrm{S})=31-50$

Resistant $(R)=51-70$

Highly resistant(HR) $=71-90$

Very Highly resistant $(\mathrm{V} \mathrm{H} \mathrm{R})=91-100$

dMean of 20 replicates (families).

Table 5.Commercial cotton cultivars supplied by Cotton Maintenance Section, Cotton. Research Institute and the frequencies (\%) of their families in each reaction class when they were tested against Fusarium wilt disease under greenhouse conditions in 2016.

\begin{tabular}{|l|c|c|c|c|c|c|c|}
\hline Cultivar & $\begin{array}{c}\text { Total no.of } \\
\text { tested families }\end{array}$ & VHR & $\begin{array}{c}\text { Reaction } \\
\text { HR }\end{array}$ & $\begin{array}{c}\text { Class (\%) } \\
\text { R }\end{array}$ & S & HS & VHS \\
\hline Giza 45 & 107 & 86.92 & 13.08 & 0.00 & 0.00 & 0.00 & 0.00 \\
\hline Giza 86 & 159 & 100.00 & 0.00 & 0.00 & 0.00 & 0.00 & 0.00 \\
\hline Giza 87 & 84 & 98.81 & 1.19 & 0.00 & 0.00 & 0.00 & 0.00 \\
\hline Giza 88 & 134 & 100.00 & 0.00 & 0.00 & 0.00 & 0.00 & 0.00 \\
\hline Giza 80 & 147 & 99.32 & 0.68 & 0.00 & 0.00 & 0.00 & 0.00 \\
\hline Giza 92 & 114 & 97.37 & 2.63 & 0.00 & 0.00 & 0.00 & 0.00 \\
\hline
\end{tabular}

a Reaction class was determined as previously mentioned in Table 4. 


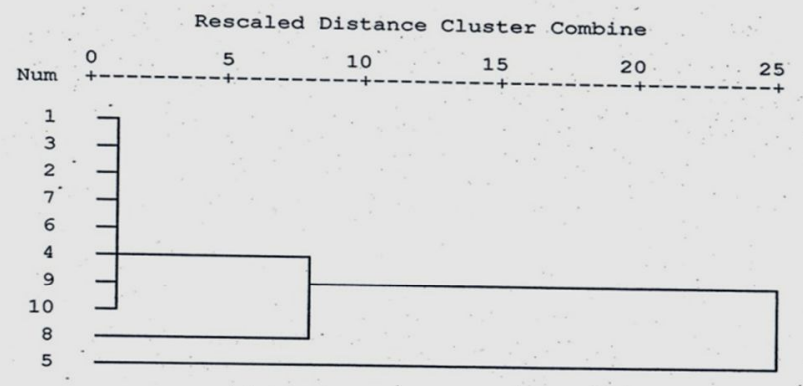

Fig.1. Phenogram based on average cluster analysis of symptom profiles of ten experimental genotypes when they inculcated with isolates of FOV race3.The tested genotypes(Gs) were G1(1),G2(2),G3(3),G4(4),G5(5),G6(6),G7(7),G8(8), G9(9), and G10(10). Pedigrees of the tested genotypes are shown in Table 1.

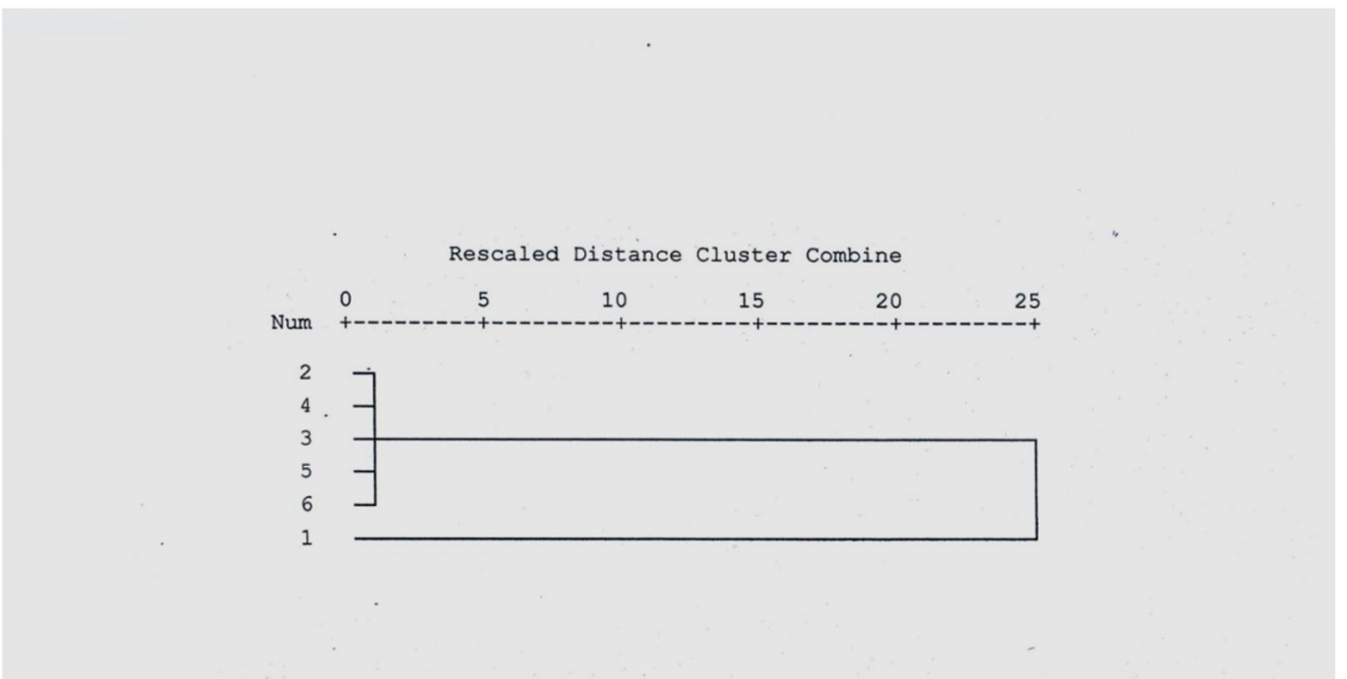

Fig.2. Phenogram based on average linkage cluster analysis of reaction classes profiles of six commercial cotton cultivars when they were inoculated with isolates of FOV race3.The tested cultivars were Giza 45(1), Giza 86(2), Giza 87(3), Giza 88(4), Giza 90(5), and Giza 92(6). 


\section{REFERENCES}

1. Abd-Elsalam, K. A., M. R. Omar, Amal A. Asran and A. A. Al. 2009. Differential Interactions among cotton genotypes, and isolates of Fusariu oxysporum Schlecht.f.sp.vasinfectum . Archives of Phytopathology and Plant Protection 42:464-473.

2. Aly, A. A., E. M. Hussin, M. R. Omar and A. M. A. El-Samawaty. 2007. Use of Protein electrophoresis to quantify resistance of cotton to Fusarium wilt disease. J. Agric. Sci. Mansoura Univ.32:3475-3488.

3. Aly, A. A., H. A. Eisa, M. T. M. Mansour, S. M. E. Zayed, and M. R. Omar. 2000. Resistance to. Fusarium wilt disease in families of some commercial cotton cultivars. In the19th Conf. of the Egyptian Phytopathological Society, 3- 4 May 2000, Giza, Egypt. pp.113-121.

4. Armstrong, G.M. and J.k. Armstrong.1978.Formae speciales and races of Fusarium oxysporum causing wilts of the Cucurbit cease. Phytopathology 68: 19 -28 .

5. Bakry, M. A., A. H. Sakre, O. A. Kassab, and R. H. Rizk. 1958. Infection of some Cotton varieties with Fusarium and possibility of the existence of Strains of thefungus. In Proc.the $2^{\text {nd }}$ Cotton Conf.(in Arabic).Giza, Egypt.

6. Doan, H. K. and R. M. Davis. 2014. Evaluation of Fusarium wilt resistance in six upland cotton germplasm lines. The Journal of Cotton Science 18:430-434.

7. Hillocks, R. J. 1984. Production of cotton varieties with resistance to Fusarium wilt with special reference to Tanzania. Tropical Pest Management 30:234- 246.

8. McFadden, H., D. Beasley, and C. L. Brubaker. 2004. Asseessment of Gossypium sturtianum and G.australe as potential sources of Fusarium wilt resistance to cotton. Euphytica 138:61-72.

9. Netzer, D. Y. Tal, A. Marani, and C. Weintall. 1985. Resistance of interspecific Cotton. hybrids (Gossypiumhirsutum x G.barbadense containing G.harknessii cytoplasm) to Fusarium wilt. Plant Dis.69:312-313. 
10. Osman, Eman, A. M. 1996. Studies on the interrelationships among some Fusarium species with special reference to their pathogenecity On cotton. Ph.D. Thesis, Cairo Univ., cairo,125pp.

11. Salgado, M. O., H. F. Schwartz, and M. A. Pastor-Corrales. 1994 Resistance To Fusarium oxysporum f.sp.phaseolin in tepary beans (phaseolus acutifolius) Plant Dis.78:357- 360.

12. Watkins, G. M. ed. 1981. Copmpendium of Cotton Diseases. The American Phytopathological Society, St. Paul, MN..87P.

13. Zink, F. W., W. D. Guber, and R. G. Grogan. 1983. Reaction of muskmelon germplasm to inoculation with Fusarium oxysporum f.sp. melonis race2.Plant Dis.67:1251-1255. 


\title{
تقييم مجموعة من الأصول الور اثية للقطن من حيث المقاومة لمرض ذبول

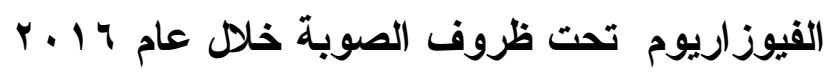

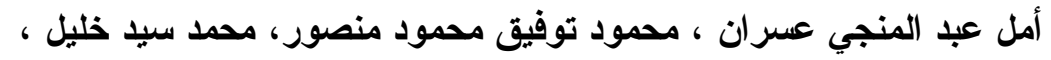 \\ عبد الودود زكي عبد الله عاثور ، ماريان منير حبيب و علي عبد الهادي علي. \\ معهُ بحوث امراض النباتات ، مركز البحوث الزرراعية ، الجيزة ، مصر
}

يهدف الاختبار الحالي إلي تقييم مجموعة من الأصول الوراثية للقطن من حيث المقاومة أو القابلية

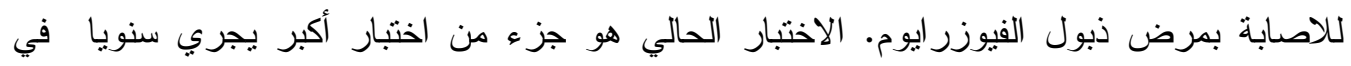

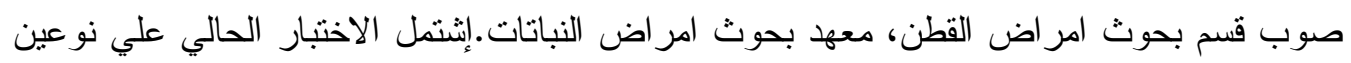

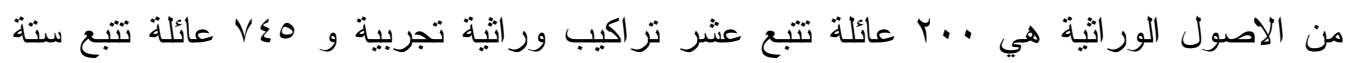

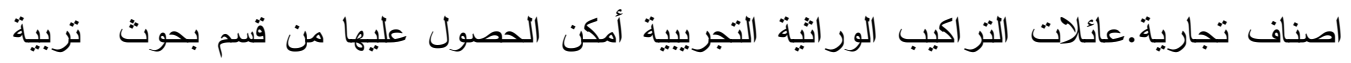

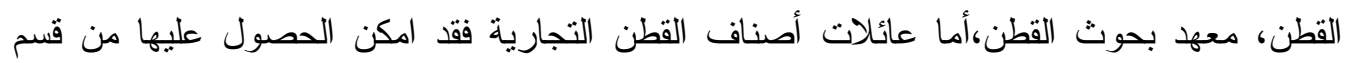
المحافظة علي أصناف القطن،معهذ بحوث القطن.إستعملت النسبة المئوية للعائلات السليمة الباقية علي قيد الحياة كمغيار للمقارنة بين الاصول الوراثية من حيث المقاومة او القابلية للاصابة

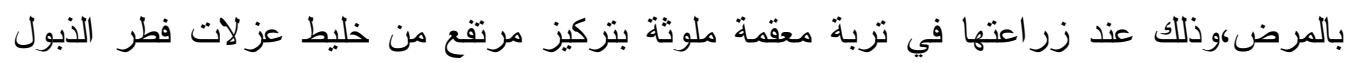

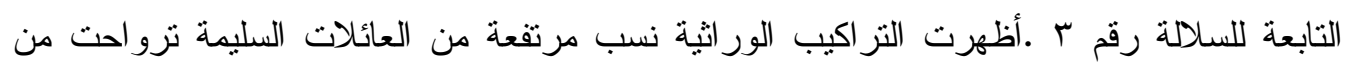

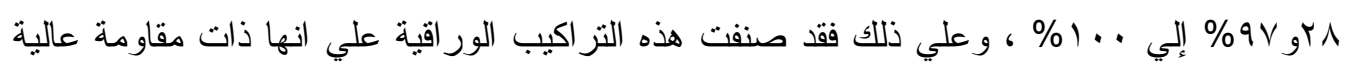

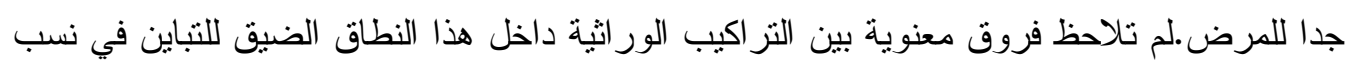

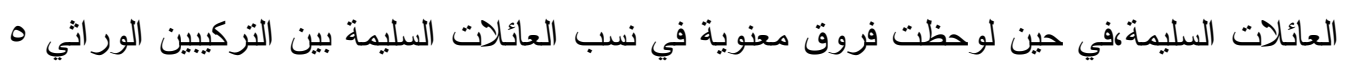

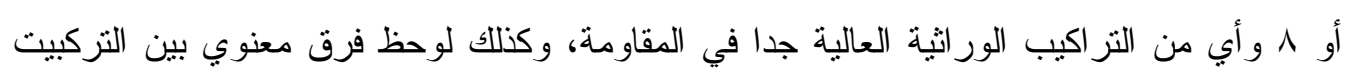

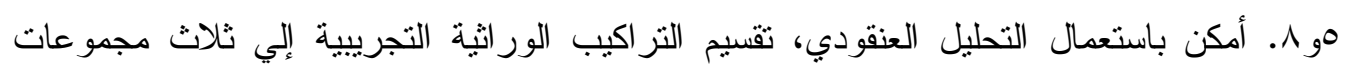

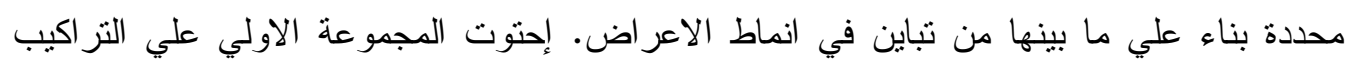

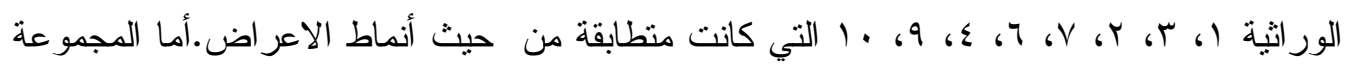

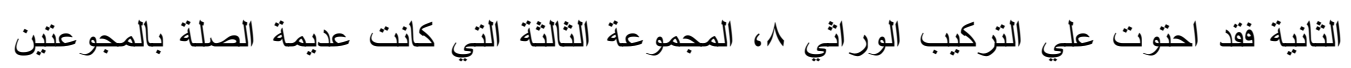
السابقتين، فقد إحتوت علي التركيب الور اثي ه منفردا. أغلب عائلات الاصناف التجارية أظهرت

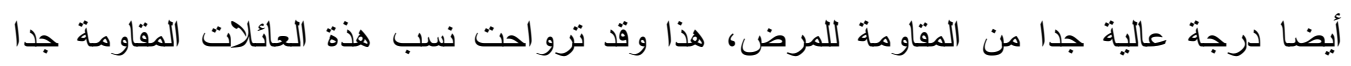

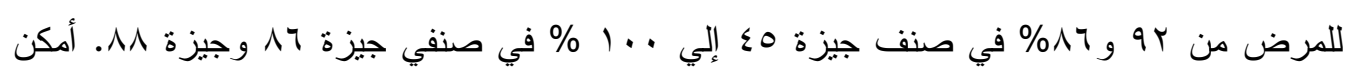

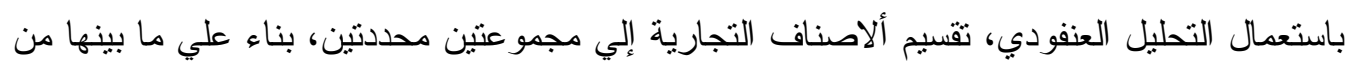

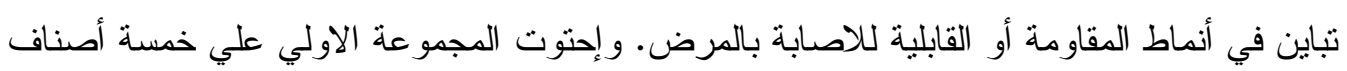
منطابقة من حيث أنماط المقاومة أو القابلية للاصابة بالمرض، أما المجموعة الثانية التي كانت عديمة الثالثة الصلة بالمجموعة الاولي فقد احتوت علي الصنف جيزة من مـ منفردا. 